\title{
Ease of Doing Business Index: An Analysis of Investors Practical View
}

\author{
Shakirat Adepeju Babatunde ${ }^{1^{*}}$, Mohammed Kayode Ajape ${ }^{2}$, Kabir Dandago Isa ${ }^{3}$, \\ Owolabi Kuye ${ }^{4}$, Eddy Olajide Omolehinwa ${ }^{5}$, Shefiu Abiodun Muritala ${ }^{6}$ \\ ${ }^{1}$ University of Lagos Business School, Akoka, Lagos, Nigeria, yasinfatiha1995@gmail.com \\ ${ }^{2}$ University of Lagos, Department of Accounting, Akoka, Lagos, Nigeria, moajape@gmail.com \\ ${ }^{3}$ Bayero University Kano, Department of Accounting, Kano, Nigeria, kidandago@gmail.com \\ ${ }^{4}$ University of Lagos, Department of Business Administration, Akoka, Lagos, Nigeria, okuye@unilag.edu.ng \\ ${ }^{5}$ University of Lagos, Department of Accounting, Akoka, Lagos, Nigeria, eddytawa@yahoo.com \\ ${ }^{6}$ Lagos State Government Treasury Office, Office of the Accountant-General, Lagos, Nigeria, \\ biodunmuritala@yahoo.com *corresponding authors
}

\begin{abstract}
This study investigates the effect of Ease of Doing Business Index (EDBI) on Return on Investment (ROI). The study employs a cross-sectional survey design covering five years from 2015 to 2019. The sample is 47 registered companies with the Lagos Chamber of Commerce and Industry, which is the most representative of the organised private sector group in Nigeria. The study adopts descriptive and linear regression statistical analysis. Findings show a statistically significant negative effect of Government policy continuity. The government procurement process, Raw materials availability and Quality of workforce show adverse effects. Traffic and transportation management, power supply and Security infrastructure show insignificant effect on ROI. Hence, findings indicate that Government procurement process is inimical to ease of doing business in Nigeria despite the government improvement efforts. Since government efforts are insufficient, the World Bank should incorporate private sector ideals into EDBI to create a synergy a robust EDBI.
\end{abstract}

Keywords: Ease of Doing Business, ease of doing business index, return on investment, investors, World Bank.

\section{Ease of Doing Business Index: Sebuah Analisis terhadap Pandangan Praktis Investor}

\begin{abstract}
Abstrak
Penelitian ini menginvestigasi pengaruh Ease of Doing Business Index (EDBI) terhadap Return on Investment (ROI). Penelitian ini menggunakan desain survei cross-sectional dari tahun 2015 sampai dengan tahun 2019. Sampel penelitian ini adalah 47 perusahaan yang terdaftar di Lagos Chamber of Commerce and Industry. Penelitian ini menggunakan analisis deskriptif dan statistik regresi linear. Dari berbagai elemen EDBI, temuan dari penelitian ini menunjukkan adanya pengaruh negatif yang signifikan antara keterlanjutan kebijakan pemerintah terhadap ROI. Proses pengadaan pemerintah, ketersediaan bahan mentah, dan kualitas tenaga kerja menunjukkan pengaruh berkebalikan dengan ROI. Lalu lintas dan manajemen transportasi, supply listrik, dan infrastruktur keamanan menunjukkan pengaruh tidak signifikan terhadap ROI. Usaha pemerintah dalam meningkatkan proses pengaadaan pemerintah masih belum memadai karena masih kecilnya pengaruh terhadap EDBI Nigeria. World Bank sebaiknya memasukkan pengaruh sektor privat dalam indikator EDBI sebagai upaya menciptakan sinergi antara pemerintah dan sektor privat untuk peningkatan EDBI dan dampaknya pada ekonomi.
\end{abstract}

Kata kunci: Ease of Doing Business, indeks kemudahan berbisnis, pengembalian investasi, investor, Bank Dunia

\section{INTRODUCTION}

The Ease of Doing Business (EDB) phenomenon is a guide established by the World Bank Group to gauge the simplicity of business operation in an environment for economic 
development. It provides information for effective governance that will lead to business growth. According to the World Bank (2020a), EDBI is an index to measure the crucial work that the countries around the globe have done to improve the operational business environment for a level playing ground for a business to thrive. EDBI covers avenues to reduce small and medium enterprises (SMEs) failures through sound regulatory policies. It accelerates policy reviews based on identified standard practices. (World Bank, 2020a).

Ease of doing business is a critical catalyst to essential economic growth for which many countries benefit. For instance, the World Bank (2020a) avers that Nigeria is one of the ten EDBI ranking improved countries based on reforms implementation. The others are Saudi Arabia, Jordan, Togo, Bahrain, Tajikistan, Pakistan, Kuwait, China, and India. 'These economies implemented 59 regulatory reforms in 2018/19, which is about one-fifth of the reforms documented, globally. They focused mainly on the regions of establishing trade, obtaining construction permits, and transaction across borders' (World Bank, 2020a, p. 8).

Nevertheless, although the EDBI report is favourable for Nigeria, the World Bank EDBI reports usually cover mainly the public sector entities and does not provide a concise analysis of the Nigerian business practitioners' view. Hence, this study focuses on Nigeria as represented by the organised private sector through the Lagos Chamber of Commerce and Industry (LCCI). Lagos Chamber of Commerce and Industry (2020a) explains that the LCCI is the major private sector group in Nigeria that hosts a fair representation of Nigerian business practitioners. The chamber delivers explanations to the Federal Government of Nigeria on business issues concerning all the States and the general economy covering the whole Federation of Nigeria. Hence, LCCI represents the Organised Private sector in Nigeria (Lagos Chamber of Commerce and Industry, 2020a).

This study is about the private sector organisations, which are the business practitioners in Nigeria. This study covers Nigeria because the Country is desirable for continuous improvement on EDB ranking. It established an EDB monitoring committee which operates through a secretariat which is the Ease of Doing Business Environment Secretariat (EBES). EBES (2018) explains that the Presidential Enabling Business Environment Council (PEBEC) was formed in July 2016 by the Nigerian President Muhammad Buhari through an Executive Order 001 with a unique mandate to remove the bottlenecks in doing business in Nigeria. The PEBEC mandate covers eight key reform agenda indicators. They are trading across the borders, entry and exit, registering property, getting electricity, getting credit, starting a business and construction permit.

Furthermore, although Nigeria EDBI ranking improved to 131 with an EDB mark of $56.9 \%$ among 190 countries ranked in 2019, her scores of 48.4 in 2016, 48.5 in 2017, 52 in 2018, 53.4 in 2019 indicate a steadily declining percentage improvement. The percentage improvement is deteriorating, with only a percentage change of $2.65 \%$ recorded between 2018 and 2019. The trend shows a decline of $4.68 \%$ from the 2018 position (World Bank, 2020b). EDBI improvement has not translated into commensurate economic development (Yusuf, 2020). For instance, Nigeria's Gross Domestic Product (GDP) per capita plunged from $\$ 2176$ in 2016 by $9.6 \%$ to $\$ 1968.56$ in 2017 (World Bank, 2020b). Although the World 
Bank attributes the disparity to the high rise in population, the decline could slow down doing business and impair the capacity of an economy for development. Hence, the motivation to eradicate the obstacles to doing business for economic development informs this study.

Given that EDBI addresses the obstacles to doing business and as such reduces the complications over an investor's ability to maximise his returns; this study aims at adding to the literature on EDBI and its aftermath effect on investment returns. The study objective is to discover which among the selected EDBI criteria affect ROI. The EDBI under focus is chosen for this study because they connect with Return on investment. They include government procurement process, traffic and transportation management, raw materials availability, power supply, quality of workforce for hire, including government policy continuity, and the strength of security infrastructure. For instance, the public sector drives the Nigerian economy; an investor can only do business with the government if he understands the government procurement process. The government procurement process is guided by legislation which is the Public Procurement Act 14, 2007 (Federal Republic of Nigeria, 2007). Traffic and transportation management is necessary for easy movement of people, goods and services. For businesses that produce, raw materials availability is essential. In contrast, all businesses require power which is regulated by the Electric Power Sector Reform Act 2005 (Federal Republic of Nigeria, 2005) in which all regulations are made centrally for all the 36 States in Nigeria.

The desired quality of the workforce is as guided by the Labour Act 2004 (Federal Republic of Nigeria, 2004). Moreover, the strength of security infrastructure is essential because the adequate security of lives and property encourages an accessible business that will generate a return on investment. All of the factors mentioned earlier could ease business operations at minimal cost, so that the business will generate an acceptable return on investment. However, although developing economies are striving to improve EDB ranking, but they are still emerging, and as such, they need to focus more on business investment attractions for further development.

The Return on investment (ROI) is under focus in this study as it could be associated with EDB because EDB initiative is for investment returns towards economic development. An investor is likely to continue in business if the investment returns are promising. Therefore, ascertaining if the EDBI would control the economic climate to influence business investment is necessary as an innovation to relying on economic growth only for measuring EDBI performance. This study, therefore, hypothesises that EDBI does not have a significant effect on ROI.

Furthermore, the dearth of scholarly contributions on EDBI debate in developing economies should improve; this study covers a Country in the transition to breach the scarcity gap. More so, this study focuses on EDB and ROI, which is novel. This study explores practitioners' observations to achieve its objectives as an addition to earlier studies. Because the input of practitioners would be an added advantage for firsthand information to guide policymaking and possibly improve the EDBI criteria, this study attempts to 
corroborate and probe further the existing scholarly research efforts. For instance, adherence to EDBI improves business performance (Doshi, Kelley, \& Simmons, 2019). Findings depict differences between the EDB indicators and actual corporate experience (Hallward-Driemeier \& Lant, 2011).

Moreover, scholars have focused on EDBI from different perspectives, but there are divergent views as to EDBI acceptance as an innovative tool to improve a Country's prestige. For instance, Bota-avram (2014) find that EDBI influence significantly business start-ups. Mongay and Filipescu (2012) find that doing business in corrupt countries is difficult. At the same time, the corruption index is omitted from the EDBI analysis of a country. Manuel (2015) finds that the causal link between investment environment reform strategy is weak. Doshi et al. (2019) find that all the variables of doing business index are statistically not significant to GDP per capita.

Corcoran and Gillanders (2015) find that no relationship exists between EDB and GDP per capita in the Sub-Saharan African Countries, based on secondary data. Thus the EDBI scholarship is emerging and requires further contributions. Hence, this study fills the gaps identified earlier in the literature.

This study is significant because it could aid governance, as it supports effective policymaking for ease of doing business. Investors would find this study useful because it could enhance a better environment that would pave ways for businesses to flourish. Academics and students would gain from this study as a basis for further research. The World Bank would benefit from this study since it could expose other areas of concern in arriving at the EDBI. Business owners and practitioners would gain from this study as they would have an insight into the issues and likely challenges to business operations in Nigeria. The study would add to the relevant body of knowledge through the methodology; the data analysis outcome for business decision making is peculiar to this study. This study also obtains practitioners' view on ease of doing business. The study harnesses the theory of change principles to explain its focus.

Discussions on EDBI vary from the conceptual position; the World Bank conceptualised the EDBI in 2002 based on the belief of Hernando De Soto in his 1980s work. According to Tamer, Pervez and Ayse (2013), the phenomenon arises on the premise that rankings and dimensions inspire governments to engage in effective policy formulation that will simplify regulation and encourage business investment. The International Finance Corporation (IFC), which is the World Bank's private-sector lending body issued the first EDB report in 2004 (Tamer et al., 2013)

The EDBI highlights areas of Government inefficiency for improvement (Bretton woods project., 2017). However, McCormack (2018) argues that ease of doing business rankings does not associate with economic development. Some countries, such as India have faulted the World Bank's EDB reports. The internal unit of the World Bank also questioned its 2012 EDB report, based on entrenched policy inclinations in some indices such as the methodology used in assessing starting a business's indicator. The method seems illusory according to the Bank's legal unit (Bretton woods project., 2017). The study argues that the Organisation for Economic Cooperation and Development (OECD) countries 
ranked higher in the Ease of Doing Business ratings because they have used their privileges to implement the form of reforms promoted by the report. However, the EDBI measures the situation on the ground, regardless of any influence.

Nonetheless, the World Bank encourages investments through the information provided about the business style of an individual Country. Moreover, Gujarati (2015) finds that the EDBI criticism is due to a misconception. For instance, EDBI became an issue when India dropped from the first position in 2015 to third in 2016, and fifth in 2017 (The Economic Times, 2018). The Country argues that its higher feedback and reform evidence score of $99.73 \%$ was ignored in the calculation. Based on the oversight, the Country challenged the ranking on the grounds of better performance than those rated higher. However, if the essence of EDBI ranking is to encourage businesses, a holistic analysis of the phenomenon is necessary to minimise the criticisms.

Therefore, this current study focus on some critical success indices of a business. The indices are carefully selected because of their likely impact on the ease of doing business. They include workforce quality. For example, workforce quality makes or mar a business. Solomon and Eno (2018) argue from organisational theory perspective that the conditions of a workforce form part of the factors that determine the fate of any business entity. Adverse fate could affect the business reputation with a dire consequence on the return on investment.

Furthermore, the stability of government policy continuity affects business. Cerna (2013) argues that policy inconsistencies could disrupt business. Besides, traffic and transportation management (TTM) is necessary for the movement of goods and services (Tseng, Yue, \& Taylor, 2005). Jibrin, Ejura and Nwaorgu (2014) find that government procurement process is complicated despite the Procurement Act 2007 existence to guide the process in Nigeria. Therefore, the knowledge of government procurement policy is crucial for a smooth business operation, to reassure the investor and minimise his risks of default in the procurement process. Singh (2019) argues that raw material availability is essential for production. It encourages production. Ram material inadequacy could affect the business turnover expectation and ultimately, the return on investment.

The strength of security infrastructure is essential for guaranteeing business continuity because insecurity has been found to retard business in Nigeria The negative consequence of insecurity led Nweke and Nwachukwu (2014) to call on the Nigerian Government to institute a formidable security structure in the Country. However, some of these issues continue to pose challenges to business success in Nigeria, calling for further examination.

The power supply is required for ease of doing business because it drives production and technology, for example. However, there are issues of erratic power supply which have grossly retarded economic development in Nigeria (USAID, 2020). The Country is unable to withstand technology to the desired level (Adewuyi et al., 2020). The Country relies on generators, inverters, solar energy and such alternatives with side effects on the environment. Most business-start-ups have liquidated because of their incapacity to 
improvise electricity at exorbitant prices. The Country's continuous darkness has distracted investors (Adewuyi et al., 2020).

Nevertheless, despite these areas of concern, Nigeria's EDB ranking improved over the years, the Country is one of the most improved Economy in terms of EDB in World Bank ranking in 2018/19 (World Bank, 2020a). For example, the EDB ranking recorded in 2018/2019 was 131 and 141 in 2017/2018 out of 190 countries ranked. Hence, the ranking difference is 3.4. The improvement continues in 2020 with a rank of 130 out of 190 moving up by 15. An analysis of the problem vis-à-vis the EDBI phenomenon shows that the focus of the World Bank is on the Government regulations while ignoring the private sector contribution. Gujarati (2015) avers that Governments concentrate on policy reforms to ginger economic growth, but the Government cannot do it alone. For instance, the provision of business enabling environment is a collective responsibility. Although infrastructure challenge is of interest to the Government in its policy reform, a joint effort with the private sector is more desirable.

Notwithstanding the criticisms, the EDBI remains the index which, the World Bank has been using to rank the countries (Doshi et al., 2019). The study argues that propagating the EDBI has contributed to reforms improvement. However, although the arguments rely on the World bank's information, they did not incorporate practitioners' view as this current study. Moreover, through the EDB Index, the World Bank has influenced governance and regulatory environment for investment attraction on the one hand and as a watch tool for leadership performance assessment on the other hand. Hallward-Driemeier and Lant (2011) explain that EDB index has promoted competition, and social burden on States to be efficient.

Moreover, the EDBI has guided leaders in meeting constituent's expectation because low EDB rank might affect their reputation. Nonetheless, sometimes the EDBI does not give detailed information to a prospective investor whose business objective is the return on investment rather than economic growth which necessitates further analysis.

Return on investment is a popular, financial concept used to assess the performance of a business. It is simple, easy to calculate and easy to understand. The numerator is the business gain. In contrast, the denominator is the capital outlay or the cost of investment (Mongollon \& Raisinghani, as cited in Botchkarev \& Andru, 2011). ROI is the cost-benefit ratio or benefit-cost ratio depending on the business policy. The interpretation of ROI depends on the formula applied for the calculation. The formulae include Net Present Value, Payback period and Profit after tax. Scholars such as Pokhrel (2015); Al-Raisi and Al-Khouri (2010) explain that ROI is measured as cost-effectiveness, cost impact or value for money system for decision making.

Both public and private institutions adopt ROI for performance measurement. The Government uses ROI to monitor the actualisation of its programme, while investors use it to measure their business performance. Botchkarev and Andru (2011) caution that ROI ignores business inefficiency and effectiveness. It is subjective, and it ignores uncertainty. However, the calculation of ROI depending on the business choice can reduce the 
criticisms. The determinant ratios contain the necessary variables. Despite the limitations, ROI continues is relevant and accessible in business matters.

The EDBI ranking concerns essential policy reforms towards achieving an improved standard of living, through the moderation of inflation (Javadekar, 2017). Since the EDBI goal is for economic improvement (Javadekar, 2017; World Bank, 2020a), the theory of change (ToC), therefore, aligns with the focus of this study. The EDBI is a global performance indicator (GPI), to achieve a change to better policies and simplify business operations in a typical environment (Doshi et al., 2019).

According to Stein and Valters (2012), ToC aids policy formulation towards achieving results. Weiss (1995) proposed ToC in 1995 when she explained that it has to do with how an idea performs in all ramifications. Stein and Valters (2012) explain that ToC involves the details of how a notion can achieve its objectives in the short and long run. The study explains that ToC demonstrates that the change activities connects with the programme actualisation. It is, therefore, necessary to connect the EDBI to the economic performance through ROI to gauge the validity of EDBI as a change object.

However, Valters (2014) cautions that the use of the ToC principle could have some distress outcomes because there is a tendency to ignore the realities on the ground affecting the people concerned. Hence, the need for this study to focus on the practitioners on the ground to minimise the concern raised. This study relies on the logic of ToC. ToC is also important because investors are demanding it as an avenue to explore change and measure change outcome (Valters, 2014)

Analysing the EDBI from the empirical angle indicates that the debate on the phenomenon dates back to the early 2000s. Some scholarly thinking ever since has evolved. However, many of the scholarly' contributions ignore the theoretical underpinning of their studies. The studies rely on secondary data; they utilised panel data time series and regression analysis to document their evidence. They established the importance of EDBI in business and economic development globally. For instance, Adepoju (2017), using panel data for 155 countries finds that the EDB has a statistically significant effect on GDP per capita. Doshi et al. (2019) apply a survey experiment of professional investors and secondary data. They find that EDB efforts shape internal politics and development programmes in the World. Although the study mentioned social pressure theory, it did not explain the doctrine in details. Rao (2018) used secondary data. The study finds that EDB has acquired widespread acceptability. Adhana and Gulati (2019) used secondary data. The study finds that India improved EDB owing to significant progress in some indicators. The Indian Government's continuous efforts over the past years yielded a remarkable result.

Furthermore, Hossain, Hassan, Shafiq and Basit (2018) also used secondary data. The statistical tool was the least square regression statistical analysis. They find that EDB indicators such as enforcing contracts show a significant positive effect on Inward Foreign Direct Investment (FDI) while establishing a business and paying taxes indicated no significant effect on Inward FDI. Corcoran and Gillanders (2015) used secondary data. Findings are that Doing Business rank is highly significant in FDI attraction. However, the 
association is significant for middle-income countries, but not for the Sub-Saharan African and the OECD countries. Their finding is supported by Nangpiire, Rodrigues and Adam (2018). Pollard, Piffaut and Shackman (2013) argue that appropriate policies towards corruption control, improved freedom, health and education enhance business infrastructure. Nevertheless, rural development accelerates EDB in a Country. Vogiatzoglou (2016) used secondary data; the study finds that EDBI significantly determines FDI in Association of Southeast Asian Nations (ASEAN) Countries.

Nevertheless, apart from the fact that the methodology adopted in most cases rely on secondary data, attention was not directed at the theoretical underpinning of most of the studies under reference. Hence, the current study diversified into survey method. Besides, appropriate theoretical underpinning arguments form the basis of the methodology.

\section{METHOD}

This study utilises a cross-sectional survey research design. Survey design is adopted because the study is about the practical experience of the business operators; the survey design allows for a more informative assessment of the real situation. The population is all the member companies of the Industrial group that registered with the Lagos Chamber of Commerce and Industry (LCCI) of Nigeria which covers the organised private sector in Nigeria, totaling 150 members. LCCI is the mouth-organ for all private organisations in Nigeria. It promotes and protects trade and industry across the Nigerian Nation (Lagos Chamber of Commerce and Industry, 2020b). SurveyMonkey (2020) was used to arrive at a sample size 47 respondents from the population, based on a confidence level of $90 \%$ and margin of error of 10\% (Qualtrics, 2019; Ryan, 2013).

The research instrument for primary data collection is a questionnaire (Appendix I). The questionnaire is carefully designed to cover the respondents' biodata in section A. Section B consists of some established EDBI in line with the indexes identified in the World bank report of 2018/2019 (World Bank, 2020c). The questionnaire measures the EDB activities of the companies covering five years from 2015 to 2019. Fifty-five copies of the questionnaire were distributed. However, only thirty-four copies were analysed due to mutilation and non-return cases.

Statistical Product and Service Solutions (SPSS) version 23 aided the data analysis. Descriptive statistics and linear regression statistical analyses are employed for the data analysis. Linear regression analysis is employed because the respondents and data collected are large enough, and they qualify for regression analysis. Linear regression is characterised by a robust predictive power which is appropriate for this study. Eventually, the data analysed summed up to 47 criteria from each of 34 respondents. Thus, the total analysed data is 1598.

In this study, the ROI is the dependent variable. The independent variable is the selected established World Bank EDBI comprising of Ease of Government Procurement Process (EGPP), Traffic and Transportation Management (TTM), Raw Materials Availability (RMA), Power Supply (PS), Quality of Workforce Available for Hire (QWH), Government Policy Continuity (GPC) and Strength of Security Infrastructure (SSI). 
Hence, ROI is a function of the independent factors upon which the actualisation of the investors' pursuit of returns is achievable. This assumption is, therefore reflected in Linear model 1 as follows:

$$
\begin{aligned}
& R O I=\beta 0+\beta 1 \mathrm{EGPP}+\beta 2 \mathrm{TTMt}+\beta 3 \mathrm{RMAt}+\beta 4 \mathrm{PSt}+\beta 5 \mathrm{QWHt}+\beta 6 \mathrm{GPCt} \\
& +\beta 7 \text { SSIt }+\varepsilon \\
& \beta 1>0, \beta 2>0, \beta 3>0, \beta 4>0, \beta 5>0, \beta 6>0 \text { and } \beta 7>0 \text {. }
\end{aligned}
$$

Where:

$\beta_{0}$ is the Intercept coefficient

$\beta$ is the Coefficient for each of the dependent variables and $\varepsilon$ is the error term.

\begin{tabular}{|c|c|c|c|}
\hline $\mathbf{S} / \mathbf{N}$ & Variable & Measurement & Frequency (\%) \\
\hline \multirow[t]{4}{*}{1} & Age of respondents' & Below 5 years & 39 \\
\hline & organisation & $5-10$ years & 25 \\
\hline & & Above 10 years & 36 \\
\hline & & Total & 100 \\
\hline \multirow[t]{4}{*}{2.} & Operational & Between $1-5$ years & 45 \\
\hline & Experience & $6-10$ years & 22 \\
\hline & & Above 10 years & 33 \\
\hline & & Total & 100 \\
\hline \multirow[t]{7}{*}{3.} & Line of Business & Educational product industry & 14 \\
\hline & & Agro-allied industry & 11 \\
\hline & & Health & 17 \\
\hline & & Hospitality and Tourism & 11 \\
\hline & & House hold products & 25 \\
\hline & & Fashion & 22 \\
\hline & & Total & 100 \\
\hline \multirow[t]{3}{*}{4.} & Number of Office & 1-5 branches & 92 \\
\hline & Branches & 6-10 branches & 8 \\
\hline & & Total & 100 \\
\hline
\end{tabular}

The data analysis results are depicted in Tables 1 to 13 .

Table 1. Respondents' Biodata

Table 1 shows that about $39 \%$ of the respondent organisations are below five years of existence and experience. While $25 \%$ of the respondent organisations are aged between 5 10 years, $36 \%$ of them are above ten years of existence. With $61 \%$ of the respondent organisations enjoying more than five years' experience in business and having much to say about EDB in Nigeria, it is clear that they are in a position to share a lot of information on government efforts to make the environment enabling for business to flourish in Nigeria.

In terms of operational experience in Nigeria, the Table reveals that $45 \%$ of the organisations sampled out had the operational experience of between 1-5 years, $22 \%$ had been in operations for a period between 6-10 years, while 33\% have over ten years' business experience. This suggests that $55 \%$ of business organisations in Nigeria have more than five years of operational experiences and they are in a position to share first-hand information on the effectiveness of the ease of doing business strategies in Nigeria. 
Jurnal Economia, 17(1), April 2021, 101 - 123

Table 2. Mean Statistics of the EDBI Measured for 2015 to 2019

\begin{tabular}{|c|c|}
\hline Variables & Mean \\
\hline 1. Ease of government procurement process (No of Days)/2015 & 1.76 \\
\hline 2. Ease of government procurement process (No of Days)/2016 & 1.53 \\
\hline 3. Ease of government procurement process (No of Days)/2017 & 1.41 \\
\hline 4. Ease of government procurement process (No of Days)/2018 & 1.69 \\
\hline 5. Ease of government procurement process (No of Days)/2019 & 1.91 \\
\hline 6. Traffic and Transportation management $(\%) / 2015$ & 1.83 \\
\hline 7. Traffic and Transportation management (\%)/2016 & 2.03 \\
\hline 8. Traffic and Transportation management (\%)/2017 & 1.93 \\
\hline 9. Traffic and Transportation management (\%)/2018 & 2.06 \\
\hline 10. Traffic and Transportation management (\%)/2019 & 2.08 \\
\hline 11. Availability of raw materials/ Goods (\%)/2015 & 2.53 \\
\hline 12. Availability of raw materials/ Goods (\%)/2016 & 2.53 \\
\hline 13. Availability of raw materials/ Goods (\%)/2017 & 2.54 \\
\hline 14. Availability of raw materials/ Goods (\%)/2018 & 2.75 \\
\hline 15. Availability of raw materials/ Goods (\%)/2019 & 2.58 \\
\hline 16. Power supply (\%)/2015 & 1.86 \\
\hline 17. Power supply (\%)/2016 & 1.76 \\
\hline 18. Power supply $(\%) / 2017$ & 1.64 \\
\hline 19. Power supply $(\%) / 2018$ & 1.75 \\
\hline 20. Power supply (\%)/2019 & 1.67 \\
\hline 21. Quality of workforce available for hire (\%)/2015 & 2.73 \\
\hline 22. Quality of workforce available for hire (\%)/2016 & 2.56 \\
\hline 23. Quality of workforce available for hire (\%)/2017 & 2.41 \\
\hline 24. Quality of workforce available for hire (\%)/2018 & 2.57 \\
\hline 25. Quality of workforce available for hire (\%)/2019 & 2.50 \\
\hline 26. Government policy continuity (\%)/2015 & 1.86 \\
\hline 27. Government policy continuity $(\%) / 2016$ & 1.90 \\
\hline 28. Government policy continuity (\%)/2017 & 1.74 \\
\hline 29. Government policy continuity $(\%) / 2018$ & 1.60 \\
\hline 30. Government policy continuity (\%)/2019 & 1.70 \\
\hline Security infrastructure (\% score)/2015 & 2.23 \\
\hline Security infrastructure (\% score)/2016 & 2.20 \\
\hline Security infrastructure (\% score)/2017 & 2.09 \\
\hline Security infrastructure (\% score)/2018 & 1.96 \\
\hline Security infrastructure (\% score)/2019 & 1.91 \\
\hline Return on investment $\% / 2015$ & 2.26 \\
\hline Return on investment $\% / 2016$ & 2.33 \\
\hline Return on investment $\% / 2018$ & 2.00 \\
\hline Return on investment $\% / 2019$ & 2.11 \\
\hline
\end{tabular}

$\mathrm{N}=34 ;$ Scale: Max. $=5 ;$ Min. $=1$

The respondent organisations in this study are into diverse business lines including educational products (14\%), agro-allied business (11\%), health (17\%), hospitality and tourism (11\%), household products business 26\%, and Fashion Design (22\%), as shown in the Table under reference. Hence, the study covers diverse areas of industrial sectors. The Table also reveals that majority of the respondent organisations (92\%) have between 1-5 branches, while $8 \%$ have between $6-10$ branches in Nigeria. The data collected are subjected to descriptive analysis, as shown in Table 2. 
Table 2 reveals the mean score for each of the measured ease of doing business (EDB) metrics. The Table reveals that the availability of raw material mean score peaked in the year 2018 (2.75) but dropped in 2019 to 2.58. The quality of workforce mean score dropped from 2.73 in the year 2015 to its lowest of 2.41 in 2017. The result implies the availability of raw materials /goods and quality workforce for hire, respectively. The ease of the government procurement process had the lowest mean score of 1.42 in 2017, which continues to decline consistently from 2015 to 2018 . The result implies that the government procurement process is still a problem. Traffic and transportation management recorded a mean score of 2.09 in 2019, which is an improvement from its mean score of 1.83 in the year 2015 .

The Table reveals that government policy continuity is inadequate, having recorded a mean score of 1.90 in 2016, with the lowest mean score of 1.61 in the year 2018. The Table also indicates that the power supply scores the lowest among all the factors. The mean score dropped from 1.86 in the year 2015 to 1.67 in 2019. The power supply is rated lowest by the respondents during the five years under consideration. The implication is that business organisations experience a power failure, which has been a problem for many decades, and a setback to EDB ranking for Nigeria.

Security infrastructure shows a mean score of 2.23 in 2015. It declines over the years to 1.91 in 2019, as shown in the Table. ROI has a mean score of 2.33 in 2015 and declines to a mean score of 2.00 in 2018 . The mixed results aggregate shows that variables that enhance the EDB ranking in Nigeria demand government sincere and real attention for improvement to a competitive level to attract investors for economic development.

Table 3. Ease of Government Procurement Process (\%)

\begin{tabular}{llllll}
\hline $\begin{array}{c}\text { Response/ } \\
\text { Years }\end{array}$ & \multicolumn{1}{c}{2015} & \multicolumn{1}{c}{2016} & \multicolumn{2}{c}{2017} & \multicolumn{2}{c}{2018} & \multicolumn{1}{c}{2019} \\
\hline Below $40 \%$ & $19(55.9 \%)$ & $21(61.8 \%)$ & $22(64.7 \%)$ & $18(52.9 \%)$ & $16(47.1 \%)$ \\
$40-50 \%$ & $4(11.8 \%)$ & $5(14.7 \%)$ & $6(17.6 \%)$ & $10(29.4 \%)$ & $9(26.5 \%)$ \\
$51-60 \%$ & $4(11.8 \%)$ & $2(5.9 \%)$ & $2(5.9 \%)$ & $2(5.9 \%)$ & $6(17.6 \%)$ \\
$61-70 \%$ & $1(2.9 \%)$ & $1(2.9 \%)$ & $1(2.9 \%)$ & $3(8.8 \%)$ & $2(5.9 \%)$ \\
$71-80 \%$ & $2(5.9 \%)$ & $1(2.9 \%)$ & - & - & $1(2.9 \%)$ \\
\hline Total & 30 & 30 & 31 & 33 & 34 \\
\hline
\end{tabular}

Table 3 shows the respondents' perception of the ease of the government procurement process. For the five years under review, the majority of the respondents rated this factor below $40 \%$ over the five years. The result implies that the respondents do not find relative ease in terms of the government procurement process, which is a significant factor in ensuring EDB.

Table 4 reveals the rating on transport and transportation management index majority of the respondents at $52.9 \%$ scored the index below $40 \%$ in 2015 . Although the score improved in 2015 and 2016, it declined in 2017 and 2018 at $44.1 \%$ and $41,2 \%$ respectively and improved again in 2019 to $47 \%$. Transport and Transportation management seems to 
Jurnal Economia, 17(1), April 2021, $101-123$

have enjoyed the best rating in the year 2016. This result shows that the index is below average.

Table 4. Transport and Transportation Management (\%)

\begin{tabular}{llllll}
\hline $\begin{array}{l}\text { Response/ } \\
\text { Years }\end{array}$ & \multicolumn{1}{c}{2015} & \multicolumn{1}{c}{2016} & \multicolumn{1}{c}{2017} & \multicolumn{1}{c}{2018} & \multicolumn{1}{c}{2019} \\
\hline Below 40\% & $18(52.9 \%)$ & $25(44.1 \%)$ & $15(44.1 \%)$ & $14(41.2 \%)$ & $16(47.1 \%)$ \\
$40-50 \%$ & $6(17.6 \%)$ & $7(20.6 \%)$ & $8(23.5 \%)$ & $9(26.5 \%)$ & $8(23.5 \%)$ \\
$51-60 \%$ & $2(5.9 \%)$ & $4(11.8 \%)$ & $4(11.8 \%)$ & $6(17.6 \%)$ & $5(14.7 \%$ \\
$61-70 \%$ & $1(2.9 \%)$ & - & $3(8.8 \%)$ & $3(8.8 \%)$ & $3(8.8 \%)$ \\
$71-80 \%$ & $3(8.8 \%)$ & $4(11.8 \%)$ & $1(2.9 \%)$ & - & - \\
Above $80 \%$ & - & - & - & $1(2.9 \%)$ & $2(5.9 \%)$ \\
Missing & $4(11.8 \%)$ & $4(11.8 \%)$ & $3(8.8 \%)$ & $1(2.9 \%)$ & - \\
\hline Total & 34 & 34 & 34 & 34 & 34 \\
\hline
\end{tabular}

Table 5. Availability of Raw Materials/Goods (\%)

\begin{tabular}{llllll}
\hline $\begin{array}{l}\text { Response/ } \\
\text { Years }\end{array}$ & \multicolumn{1}{c}{2015} & \multicolumn{1}{c}{2016} & \multicolumn{1}{c}{2017} & \multicolumn{1}{c}{2018} & \multicolumn{1}{c}{2019} \\
\hline Below 40\% & $8(23.5 \%)$ & $8(23.5 \%)$ & $7(20.6 \%)$ & $5(14.7 \%)$ & $10(29.4 \%)$ \\
$40-50 \%$ & $11(32.4 \%)$ & $10(29.4 \%)$ & $11(32.4 \%)$ & $13(38.2 \%)$ & $10(29.4 \%)$ \\
$51-60 \%$ & $4(11.8 \%)$ & $5(14.7 \%)$ & $7(20.6 \%)$ & $7(20.6 \%)$ & $7(20.6 \%)$ \\
$61-70 \%$ & $2(5.9 \%)$ & $3(8.8 \%)$ & $1(2.9 \%)$ & $2(5.9 \%)$ & - \\
$71-80 \%$ & $4(11.8 \%)$ & $3(8.8 \%)$ & $5(14.7 \%)$ & $5(14.7 \%)$ & $5(14.7 \%)$ \\
Above $80 \%$ & $1(2.9 \%)$ & $1(2.9 \%)$ & & $1(2.9 \%)$ & $2(5.9 \%)$ \\
Missing & $4(11.8 \%)$ & $4(11.8 \%)$ & $3(8.8 \%)$ & $1(2.9 \%)$ & - \\
\hline Total & 34 & 34 & 34 & 34 & 34 \\
\hline
\end{tabular}

Table 6. Power Supply (\%)

\begin{tabular}{|c|c|c|c|c|c|}
\hline$\frac{\text { Response/ }}{\text { Years }}$ & $\underline{2015}$ & $\underline{2016}$ & $\underline{2017}$ & $\underline{2018}$ & $\underline{2019}$ \\
\hline Below 40\% & $18(52.9 \%)$ & $17(50.0 \%)$ & $19(55.9 \%)$ & $17(50.0 \%)$ & $19(55.9 \%)$ \\
\hline $40-50 \%$ & $4(11.8 \%)$ & $8(23.5 \%)$ & $7(20.6 \%)$ & $8(23.5 \%)$ & $8(23.5 \%)$ \\
\hline $51-60 \%$ & $4(11.8 \%)$ & $1(2.9 \%)$ & $2(5.9 \%)$ & $7(20.6 \%)$ & $6(17.6 \%)$ \\
\hline $61-70 \%$ & $2(5.9 \%)$ & $3(8.8 \%)$ & $3(8.8 \%)$ & $1(2.9 \%)$ & $1(2.9 \%)$ \\
\hline $71-80 \%$ & $2(5.9 \%)$ & $1(2.9 \%)$ & - & - & - \\
\hline Above $80 \%$ & - & - & - & - & - \\
\hline Missing & $4(11.8 \%)$ & $4(11.8 \%)$ & $3(8.8 \%)$ & $1(2.9 \%)$ & - \\
\hline Total & 34 & 34 & 34 & 34 & 34 \\
\hline
\end{tabular}

In Table 5, the respondents' percentage rating of the availability of raw materials is mainly between $40-50 \%$ throughout the five years under reference. Respondents affirm that the availability of raw materials is between $40 \%$ and $50 \%$ of the requirement for meeting their EDB expectation.

Table 6 shows that the power supply is rated below $40 \%$ of the needed capacity. Generally, the Table shows that power supply is relatively below the expectation of what businesses require to function properly in the Nigerian business environment. The result 112 
shows that without adequate power supply businesses would be unable to function effectively to its optimum capacity.

Table 7. Quality of Workforce Available for Hire (\%)

\begin{tabular}{llllll}
\hline $\begin{array}{c}\text { Response/ } \\
\text { Years }\end{array}$ & \multicolumn{1}{c}{2015} & \multicolumn{1}{c}{2016} & \multicolumn{1}{c}{2017} & \multicolumn{1}{c}{2018} & \multicolumn{1}{c}{2019} \\
\hline Below $40 \%$ & $5(14.7 \%)$ & $8(23.5 \%)$ & $7(20.6 \%)$ & $5(14.7 \%)$ & $7(20.6 \%)$ \\
$40-50 \%$ & $9(26.5 \%)$ & $7(20.6 \%)$ & $10(29.4 \%)$ & $13(38.2 \%)$ & $12(35.3 \%)$ \\
$51-60 \%$ & $9(26.5 \%)$ & $9(26.5 \%)$ & $10(29.4 \%)$ & $8(23.5 \%)$ & $8(23.5 \%)$ \\
$61-70 \%$ & $3(8.8 \%)$ & $2(5.9 \%)$ & $2(5.9 \%)$ & $5(14.7 \%)$ & $5(14.7 \%)$ \\
$71-80 \%$ & $4(11.8 \%)$ & $4(11.8 \%)$ & $2(5.9 \%)$ & $2(5.9 \%)$ & $2(5.9 \%)$ \\
Above $80 \%$ & - & - & - & & - \\
Missing & $4(11.8 \%)$ & $4(11.8 \%)$ & $3(8.8 \%)$ & $1(2.9 \%)$ & - \\
\hline Total & 34 & 34 & 34 & 34 & 34 \\
\hline
\end{tabular}

Table 7 reveals that the quality of the workforce to hire scores between $40 \%-60 \%$. This index enjoys consistent rating by the respondents throughout the five years. In 2015 it was 53\%, in 2017 and 2019 it was 59\%, while in 2018 it was 62\%. This shows that the quality workforce is available in the Nigerian business environment, thereby enhancing the EDB rating of the Country.

Table 8. Government Policy Continuity (\%)

\begin{tabular}{llllll}
\hline $\begin{array}{c}\text { Response } \\
\text { Years }\end{array}$ & \multicolumn{1}{c}{2015} & \multicolumn{1}{c}{2016} & \multicolumn{2}{c}{2017} & \multicolumn{2}{c}{2018} & \multicolumn{1}{c}{2019} \\
\hline Below $40 \%$ & $17(50.0 \%)$ & $15(44.1 \%)$ & $16(47.1 \%)$ & $18(52.9 \%)$ & $19(55.9 \%)$ \\
$40-50 \%$ & $6(17.6 \%)$ & $7(20.6 \%)$ & $9(26.5 \%)$ & $12(35.3 \%)$ & $10(29.4 \%)$ \\
$51-60 \%$ & $4(11.8 \%)$ & $6(17.6 \%)$ & $4(11.8 \%)$ & $1(2.9 \%)$ & $3(8.8 \%)$ \\
$61-70 \%$ & - & - & $2(5.9 \%)$ & $2(5.9 \%)$ & $1(2.9 \%)$ \\
$71-80 \%$ & $3(8.8 \%)$ & $2(5.9 \%)$ & - & - & - \\
Above $80 \%$ & - & - & - & & $1(2.9 \%)$ \\
Missing & $4(11.8 \%)$ & $4(11.8 \%)$ & $3(8.8 \%)$ & $1(2.9 \%)$ & - \\
\hline Total & 34 & 34 & 34 & 34 & 34 \\
\hline
\end{tabular}

In Table 8 , government policy is rated consistently below $40 \%$ and between $41 \%-50 \%$. Thus, respondents believe that government policy is relatively stable. However, the government policies that appear consistent are fiscal because monetary policies now being stabilised in the Country.

Table 9 shows that most respondents rate security infrastructure below $40 \%$ for all the five years. On average, security infrastructure only improved between 2016 and 2018. It deteriorated in the year 2019. That security apparatus scores below $40 \%$ suggests that the index requires more attention to improve $\mathrm{EDB}$ and attract investor. 
Jurnal Economia, 17(1), April 2021, 101 - 123

Table 9. Security Infrastructure (\%)

\begin{tabular}{llllll}
\hline $\begin{array}{c}\text { Response/ } \\
\text { Years }\end{array}$ & \multicolumn{2}{c}{2015} & \multicolumn{2}{c}{2016} & \multicolumn{2}{c}{2017} & \multicolumn{2}{c}{2018} & \multicolumn{1}{c}{2019} \\
\hline Below $40 \%$ & $12(35.3 \%)$ & $10(29.4 \%)$ & $13(38.2 \%)$ & $13(38.2 \%)$ & $15(44.1 \%)$ \\
$40-50 \%$ & $8(23.5 \%)$ & $12(35.3 \%)$ & $9(26.5 \%)$ & $13(38.2 \%)$ & $12(35.3 \%)$ \\
$51-60 \%$ & $5(14.7 \%)$ & $4(11.8 \%)$ & $5(14.7 \%)$ & $5(14.7 \%)$ & $5(14.7 \%)$ \\
$61-70 \%$ & $2(5.9 \%)$ & $1(2.9 \%)$ & $2(5.9 \%)$ & - & - \\
$71-80 \%$ & $2(5.9 \%)$ & $2(5.9 \%)$ & $1(2.9 \%)$ & $1(2.9 \%)$ & $1(2.9 \%)$ \\
Above $80 \%$ & $1(2.9 \%)$ & $1(2.9 \%)$ & $1(2.9 \%)$ & $1(2.9 \%)$ & $1(2.9 \%)$ \\
Missing & $4(11.8 \%)$ & $4(11.8 \%)$ & $3(8.8 \%)$ & $1(2.9 \%)$ & - \\
\hline Total & 34 & 34 & 34 & 34 & 34 \\
\hline
\end{tabular}

Table 10. Return on Investment (\%)

\begin{tabular}{llllll}
\hline $\begin{array}{c}\text { Response/ } \\
\text { Years }\end{array}$ & \multicolumn{1}{c}{2015} & \multicolumn{1}{c}{2016} & \multicolumn{2}{c}{2017} & \multicolumn{2}{c}{2018} & 2019 \\
\hline Below $40 \%$ & $12(35.3 \%)$ & $9(26.5 \%)$ & $14(41.2 \%)$ & $16(47.1 \%)$ & $15(44.1 \%)$ \\
$40-50 \%$ & $8(23.5 \%)$ & $11(32.4 \%)$ & $6(17.6 \%)$ & $7(20.6 \%)$ & $8(23.5 \%)$ \\
$51-60 \%$ & $5(14.7 \%)$ & $6(17.6 \%)$ & $7(20.6 \%)$ & $6(17.6 \%)$ & $6(17.6 \%)$ \\
$61-70 \%$ & $2(5.9 \%)$ & $1(2.9 \%)$ & $2(5.9 \%)$ & $3(8.8 \%)$ & $3(8.8 \%)$ \\
$71-80 \%$ & $1(8.8 \%)$ & $1(2.9 \%)$ & $1(2.9 \%)$ & - & $1(2.9 \%)$ \\
Above $80 \%$ & $2(5.9 \%)$ & $2(5.9 \%)$ & $1(2.9 \%)$ & $1(2.9 \%)$ & $1(2.9 \%)$ \\
Missing & $4(11.8 \%)$ & $4(11.8 \%)$ & $3(8.8 \%)$ & $1(2.9 \%)$ & - \\
\hline Total & 34 & 34 & 34 & 34 & 34 \\
\hline
\end{tabular}

Table 10 indicates that the highest percentage score of $47.1 \%$ on ROI occurred in 2018. Majority of the respondents scored ROI below $40 \%$ across the five years. However, for the year 2016, the score was in the $40-50 \%$ category. This declining trend indicates low ease of doing business in Nigeria since adequate returns on investment suggests the availability of an enabling environment. Tables 11 to 13 depict the linear regression statistical analysis results.

\section{Linear regression results:}

In Table 12, the R-square shows the proportion of ROI forecast by the inducing indexes, which is to the extent of .875 . The adjusted R-squared of .650, affirms the large extent of the predictive power of the indexes. The output is conditional because the Rsquared is less than 1 , but it is reliable being greater than .5. This result indicates that .65 is the proportion of the variance of ROI that is predicted by the influencing factors tested. The result implies that other indexes that may be affecting the ROI in Nigeria exist apart from the EDB indexes tested in this study. The standard error stands at .039 for the estimate which is less than .5. The result indicates that the annotations are closer to the fitted line. Hence, the regression line is of good fit and reliable. Table 12 shows a Durbin-Watson score of 1.65, which indicates that the data used for the regression analysis are free from bias. Frost (2013) explains that an acceptable Durbin-Watson score should be between 0 and 4 and that a score of 0 to 2 shows that data tested are free from bias. 
Table 11. ANOVA of the effect of EDB Index on ROI measurement

\begin{tabular}{|c|c|c|c|c|c|c|}
\hline Model & & $\begin{array}{l}\text { Sum } \\
\text { Squares }\end{array}$ & Df & $\begin{array}{l}\text { Mean } \\
\text { Square }\end{array}$ & $\mathrm{F}$ & Sig. \\
\hline \multirow[t]{3}{*}{1} & Regression & 35.761 & 11 & 3.251 & 6.561 & $.000^{\mathrm{b}}$ \\
\hline & Residual & 10.900 & 22 & .495 & & \\
\hline & Total & 46.662 & 33 & & & \\
\hline
\end{tabular}

Table 12. Model Summary of the Linear regression analysis of the effect of EDB Index on ROI

\begin{tabular}{lllllll}
\hline Model & $\mathrm{R}$ & $\begin{array}{l}\mathrm{R} \\
\text { Square }\end{array}$ & $\begin{array}{l}\text { Adjusted } \\
\text { Square }\end{array}$ & $\mathrm{R}$ & $\begin{array}{l}\text { Std. Error } \\
\text { Estimate }\end{array}$ & of the \\
\hline 1 & $.875^{\mathrm{a}}$ & .766 & .65 & $\begin{array}{l}\text { Durbin- } \\
\text { Watson }\end{array}$ \\
\hline
\end{tabular}

Table 13. Coefficients of the research variables

\begin{tabular}{|c|c|c|c|c|c|c|c|c|}
\hline & & \multicolumn{2}{|c|}{$\begin{array}{l}\text { Unstandardized } \\
\text { Coefficients }\end{array}$} & \multicolumn{2}{|l|}{$\begin{array}{l}\text { Standardized } \\
\text { Coefficients }\end{array}$} & & \multicolumn{2}{|c|}{$\begin{array}{l}95.0 \% \text { Confidence Interval } \\
\text { for B }\end{array}$} \\
\hline \multicolumn{2}{|c|}{ Model } & B & $\begin{array}{l}\text { Std. } \\
\text { Error }\end{array}$ & Beta & $\mathrm{T}$ & Sig. & $\begin{array}{l}\text { Lower } \\
\text { Bound }\end{array}$ & Upper Bound \\
\hline \multirow[t]{8}{*}{1} & (Constant) & .454 & .427 & & 1.062 & .300 & -.432 & 1.340 \\
\hline & $\begin{array}{l}\text { Government procurement } \\
\text { process }\end{array}$ & -.139 & 206 & -.087 & -.676 & .506 & -.566 & .288 \\
\hline & $\begin{array}{ll}\text { Traffic \& } & \text { Transport } \\
\text { Management. } & \end{array}$ & .230 & .287 & .212 & .799 & .433 & -.367 & .826 \\
\hline & Raw Materials availability & -.005 & .159 & -.006 & -.034 & .973 & -.336 & .325 \\
\hline & Power Supply & .136 & .340 & .098 & .401 & 692 & -.568 & .841 \\
\hline & Quality of workforce & -.145 & .152 & -.131 & -.953 & .351 & -.461 & .171 \\
\hline & $\begin{array}{l}\text { Government } \\
\text { Continuity }\end{array}$ & -.718 & .283 & -.544 & -2.534 & .019 & -1.306 & -.130 \\
\hline & $\begin{array}{l}\text { Strength of Security } \\
\text { Infrastructure }\end{array}$ & .123 & .205 & .112 & .602 & .554 & -.302 & .548 \\
\hline
\end{tabular}

Dependent Variable: Return on Investment

Table 13 shows the research variables coefficients. Out of all the indexes tested, the $\beta$ coefficients have negative and statistically significant effect on ROI for government policy continuity only at .05 level of significance. The $\beta$ coefficients have not statistically significant effect on ROI for traffic and transportation management, power supply and the strength of security infrastructure. The $\beta$ coefficients have adverse, not statistically significant effects on ROI for ease of government procurement process, raw materials availability, and quality of workforce for hire at .05 level of significance, respectively.

Therefore, the results support the null hypothesis for traffic and transportation, power supply and the strength of security infrastructure. The findings also support the null hypothesis for the government procurement process, raw materials availability, and quality of workforce available for hire. However, the result does not support the null hypothesis for government policy continuity. Government policy continuity is affecting ROI negatively, which is due to the inconsistency in the monetary policy measures being taken by the Nigerian government over the years. Other reasons could be due to corruption. Hence, the need to be more explicit about the benefactor of the policy. Vogel (2014) argues that ToC allows results and performance measurement systems to be more explicit and solidifies the agenda to accomplish the intent of the international advance community. 


\section{FINDING AND DISCUSSION}

The finding shows a negative statistically significant effect of government policy continuity on return on investment at .05 level of significance. This result supports the findings in Makinde (2005). The negative effect could probably be because the Nigerian, monetary policy system has made the economy to deteriorate over time. Makinde (2005) finds that government policy continuity is lacking in Nigeria, which leads to implementation gaps.

The not statistically significant results for traffic and transportation management supports the findings in Agbigbe (2016) The result indicates that traffic and transportation management in Nigeria does not affect ROI. However, Nigeria has engaged in some improvement efforts through multi-modal means of transportation using aviation, waterway, road, and rail to ease traffic congestion. The effort could foster economic development such as in improved job creation. Although, the governments at the federal and states levels, have not met the practitioners' expectation in this regard. Hence, private sector support is necessary, because economic development should be a joint programme of all operators in the economy, not only governments.

Raw materials availability shows adverse not significant effects on ROI. This result is contrary to expectation because of Nigeria's wealth of natural resources such as coal and timber (Akpan \& Chuku, 2014). Hence, the endowment should affect the return on investment positively with statistical significance. The insignificance effect of power supply to return on investment supports the findings in Sambo, Garba, Zarma and Gaji (2010). The findings show that the power supply is not contributing to ROI. Table 4.6 reveals the disappointment of practitioners in low power availability which makes business to be complicated in Nigeria. Adewuyi et al. (2020) find that electricity supply in Nigeria is low at $3 \%$ proportion to the population. Despite the power challenges in Nigeria as supported by Sambo et al. (2010), practitioners have improvised for power sufficiently.

The situation on the ground is that practitioners have experienced power problem consistently over a long time that it does not affect ROI any more. Otherwise, the erratic power supply could have grossly retarded economic development because the business operation requires electricity. Adewuyi et al. (2020) explain that the Country relies on generators, inverters, solar energy, and such other alternatives sources of electricity with side effects on the environment. The finding on the workforce quality shows an inverse statistically insignificant effect on the return on investment. The strength of security infrastructure shows a statistically insignificant effect on return on investment. It supports the findings in Ayeni and Beji (2019); Hallward-Driemeier and Lant (2011); Asongu and Odhiambo, (2019).

Another result of note is that the government procurement process has a negative, insignificant effect on ROI at a 5\% level, which supports the findings in Inebubaraye (2013). The result means that the government procurement process harms ROI. The adverse posture of the government procurement process towards ROI implies that business operators find it challenging to post sufficient returns on their businesses. Inebubaraye (2013); Mongay and Filipescu (2012) aver that the government procurement process is a problem due to corruption, due to non-compliance with the provisions of Public 
Procurement Act 2007. This low compliance negatively affects the business operators' efforts to achieve a high level of ROI. Besides, although there had been many sensational corruption cases, the culprits are set free, especially under plea-bargain legal procedures. The immunity clause contained in the 1999 Constitution of the Federal Republic of Nigeria is mitigating the fight against corruption.

The findings on raw materials availability and quality of the workforce imply that investors experience challenges in doing business in the two areas. In contrast, the Country's productive workforce consists of skilled and unskilled labour. Corcoran and Gillanders (2015) find that EDBI shows a not significant relationship with GDP per capita in SubSaharan Africa. In this study also, the preceding discussion shows that doing business in Nigeria is difficult, despite the government's efforts at the federal and states levels. Hence, the Government alone cannot achieve ease of doing business. The private sector attention and involvement to some of these indexes would improve the business environment. Highlighting the private sector role in EDB index could also ginger improved government policy continuity. Weiss (1995) argues that a programme should benefit the people as highlighted in the theory of Change. All the indexes investigated require improvement at different degrees as aforementioned to achieve improved ease of doing business in Nigeria.

\section{CONCLUSION}

Given the results, Government Policy Continuity (DPC) is the apparent EDBI that negatively and significantly affects the ROI, using sampled responses drawn from Nigerian business practitioners. Other EDBI including raw material availability, government procurement process, traffic and transportation management, power supply, quality of the workforce, and strength of security infrastructure adversely affect ROI but not significant.

The adverse effects could harm economic development because they contradict ease of doing business, which could be counterproductive. The indexes require close monitoring for improvement. This study satisfies the ToC doctrine by highlighting change areas for the World Bank and government attention. On the whole, this study added to the current body of knowledge in some ways. For instance, as a novelty, the study focuses on doing business practise. The study has added another variable of returns on investment in ease of doing business research. This study covers a developing economy by bridging the shortage gap of such research. The Study utilises an innovation of primary data survey for EDBI analysis. Given the initial findings and conclusion of the study, the recommendations as follows:

1. Government fiscal and other policies should exhibit continuity, to ease business and attract investors.

2. The adverse effects of raw material and workforce availability on ROI despite the country's natural resources endowment and agile population call for concern. Therefore, the Government should engage its available workforce to tap the natural resources to ease business operation.

3. The World Bank should include private operators' economic contributions index to the EDBI measures of a Country. 
4. The practitioners' experiences, such as in Joint venture and other public-private partnership initiatives, are essential to improve the statistics on EDBI.

5. The World Bank should consider the need for synergy between the Government and private sector operators for a robust EDBI ranking of an economy.

6. The procurement system, which is enjoying the backing of the Public Procurement Act (PPA) 2007, should be practically and sincerely institutionalised in Nigeria.

7. This study focuses on only seven items of EDBI. Further study could cover other EDBI.

\section{REFERENCES}

Adepoju, U. K. (2017). Ease of doing business and economic growth. Master Thesis submitted to the department of economics, University of Ottawa. Retrieved from https://ruor.uottawa.ca/handle/10393/37176.

Adewuyi, O. B., Kiptoo, M. K., Afolayan, A. F., Amara, T., Alawode, O. I., \& Senjyu, T. (2020). Challenges and prospects of Nigeria's sustainable energy transition with lessons from other countries' experiences,. ENERGY Report(6), 993-1009. doi:https://doi.org/10.1016/j.egyr.2020.04.022.

Adhana, D., \& Gulati, N. (2019). Ease of doing business: A comparative study of India with BRICS and SAARC countries. International Journal of Management, IT \& Engineering, 9(5), 267-288. Retrieved from http://www.ijmra.us.

Agbigbe, W. A. (2016). The impact of transportation infrastructure on Nigeria's economic development. Doctoral dissertation in Management, Walden University, Minneapolis. Retrieved September 27, 2020, from https://scholarworks.waldenu.edu/dissertations/2778/.

Akpan, G. E., \& Chuku, C. (2014). Natural resources, human capital and economic development in Nigeria: Tracing the linkages. Journal of economics and sustainable development, $\quad 5, \quad 44-50 . \quad$ Retrieved from https://www.iiste.org/Journals/index.php/JEDS/article/view/16165.

Al-Raisi, A. N., \& Al-Khouri, A. A. (2010). Public value and ROI in the government sector. Advances in Management, 3(2), 1-6. Retrieved from https://www.coursehero.com/file/85992912/Public-Value-and-ROI-in-theGovernment-Spdf/.

Asongu, S. A., \& Odhiambo, N. M. (2019). Challenges of doing business in Africa: A systematic review, , 20 (2), 259-268, . Journal of African Business, 20(2). doi:10.1080/15228916.2019.1582294.

Ayeni, E. O., \& Beji, B. G. (2019). Security implication of infrastructural development in Nigeria: 2010-2015. Review of Public Administration and Management, 7(14), 15-24. Retrieved

from https://www.researchgate.net/publication/330534105_SECURITY_IMPLICATI ON.

Bota-avram, C. (2014). Good governance and doing business: evidence from a crossCountry survey. Transylvanian Review of Administrative Sciences(41), 27-45. Retrieved from https://doaj.org/article/8a6d578336e5432faa00c8cc56cb2d4c. 
Botchkarev, A., \& Andru, P. (2011). A Return on investment as a metric for evaluating information systems: Taxonomy and application. Interdisciplinary Joumal of Information, Knowledge, and Management, 6, 247-268. Retrieved from http://www.ijikm.org/Volume6/IJIKMv6p245-269Botchkarev566.pdf.

Bretton woods project. (2017). A bad business: Bank divisions on doing business revealed. . Retrieved July 7, 2020, from https://www.brettonwoodsproject.org.

Cerna, L. (2013). The nature of policy change and implementation: A review of different theoretical approaches. $\quad$ Retrieved $\quad$ September 10, 2020, from https://www.oecd.org/education/ceri/The\%20Nature\%20of\%20Policy\%20Chan ge.

Corcoran, A. \& Gillanders, R. (2015). Foreign direct investment and the ease of doing business. Review of World Economics, 15(1), 103-126. doi: 10.1007/s10290-014-01945.

Doshi, R., Kelley, J., \& Simmons, B. (2019). The power of ranking: The ease of doing business indicator and global regulatory behaviour. International Organisation, Cambridge University Press, 73(3), 611-643. doi:10.1017/S0020818319000158.

Ease of Doing Business Environment Secretariat (EBES). (2018). The mandate. Retrieved September 9, 2020, from https://easeofdoingbusinessnigeria.com/about-us/thereform-agenda.

Federal Republic of Nigeria. (2004). Labour Act (Cap L1 LFN2004). Federal Republic of Nigeria. Retrieved November 23, 2020, from www.ilo.org.

Federal Republic of Nigeria. (2005). Electric Power Sector Reform Act No. 6 2005. Federal Republic of Nigeria. Retrieved November 22, 2020, from www.bpe.gov.ng.

Federal Republic of Nigeria. (2007). Public Procurement Act No. 14. Federal Republic of Nigeria. Retrieved from www.bpe.gov.ng.

Gujarati, H. (2015). Ease of doing business ranking reflects the goodness of the economy: A misconception or fact?. Retrieved April 16, 2020, from https://www.researchgate.net/publication/305778407.

Hallward-Driemeier, M., \& Lant, P. (2011). How business is done and the 'doing business' indicators:The investment climate when firms have climate control. World Bank Policy Research Working Paper Series (5563). Retrieved from https://doi.org/10.1596/1813-9450-5563.

Hossain, M. T., Hassan, Z., Shafiq, S., \& Basit, A. (2018). Ease of doing business and its impact on inward FDI. Indonesian. Journal of Management and Business Economics, 1(1), 52-65. Retrieved from https://papers.ssrn.com/sol3/papers.cfm?abstract_id=3219641.

Inebubaraye, J. (2013). A critical analysis of immunity clause under the 1999 constitution of the federal republic of Nigeria. Retrieved August 2, 2020, from https://ssrn.com/abstract $=2697503$.

Javadekar, A. (2017). Why the ease of doing business matters? Retrieved September 27, 2020, from www.livemint.com. 
Jibrin, M. S., Ejura, S. B., \& Nwaorgu, I. A. (2014). The Public Procurement Reforms in Nigeria: Implementation and Compliance Challenges. Journal of Asian Business Strategy, 4(11), 149-162. Retrieved from https://econpapers.repec.org/article/asijoabsj/2014_3ap_3a149-162.htm.

Lagos Chamber of Commerce and Industry. (2020a). Profile. Retrieved September 14, 2020, from https://www.lagoschamber.com/lcci-comments-on-second-quarter-gdpreport.

Lagos Chamber of Commerce and Industry. (2020b). Services of the LCCI. Annual report. Retrieved from https://www.lagoschamber.com.

Makinde, T. (2005). Problems of policy implementation in developing Nations: The Nigerian experience,. Journal of Social Sciences, 11(1), 63-69. doi:, doi:10.1080/09718923.2005.11892495.

Manuel, C. (2015). Is there a causal link between investment climate and growth? Retrieved on July 7, 2020 from. Retrieved July 7, 2020, from https://assets.publishing.service.gov.uk/media.

McCormack, G. (2018). Why 'doing business' with the World Bank may be bad for you. European Business Organisation Law Review, 649-676 doi:https://doi.org/10.1007/s40804-018-0116-4.

Mongay, J., \& Filipescu, D. A. (2012). Are Corruption and Ease of Doing Business Correlated? An Analysis of 172 Nations. In S. Harris, O. Kuivalainen, \& V. Stoyanova, The Academy of International Business (International Business ed.). London, England: Palgrave Macmillan. doi: https://doi.org/10.1057/9781137007742_2.

Nangpiire, C., Rodrigues, R., \& Adam, I. O. (2018). Ease of doing business and foreign direct investment inflow among Sub-Sahara African countries. International Journal of Business and Emerging Markets, 10(3), 289-303. doi:org/10.1504/IJBEM.

Nweke, P., \& Nwachukwu, T. S. (2014). National security issues and challenges in Nigeria: Which way forward? nternational Journal of Youth Empowerment and Entrepreneurship Development, 1(1), 96-106. Retrieved from http://www.ijyeedjournal.com.

Pokhrel, S. (2015). Return on investment (ROI) modelling in public health: strengths and limitations. European Journal of Public Health, 25(6), 908-909. doi:10.1093/eurpub/ckv136.

Pollard, K. S., Piffaut, S. V., \& Shackman, J. (2013). Business infrastructure and the ease of doing business. Journal of Economics, Management and Trade, 3(3), 224-241. doi: https://doi.org/10.9734/BJEMT/2013/3671.

Qualtrics. (2019). Sample size calculator. Retrieved from qualtrics.com.

Rao, K. P. (2018). A study on the ease of doing business in India: Problems and prospectus. International Journal of Management, IT \& Engineering, 8(3), 299-307. Retrieved from https://www.ijmra.us/2018ijmie_march.php.

Ryan, T. P. (2013). Sample size determination and power. New York, USA: John Wiley \& Sons Incorporated. doi:10.1002/9781118439241. 
Sambo, A., Garba, B., Zarma, I., \& Gaji, M. (2010). Electricity generation and the present challenges in the Nigerian power sector. Journal of Energy Power Engineering, 6, 1-17. Retrieved from https://www.researchgate.net/signup.SignUp.html?hdrsu=1.

Singh, R. (2019). Small players hope retail policy will improve ease of doing business. . Business Line On Campus (BLOC). Retrieved September 20, 2020, from https://bloncampus.thehindubusinessline.com.

Solomon, O. A., \& Eno, E. J. (2018). Workforce diversity management in Nigeria public service: Problems and prospects. Global Journal of Human Resources Management, 6(1), 35-50. Retrieved from https://www.eajournals.org/wpcontent/uploads/Workforce-Diversity-Man.

Stein, D., \& Valters, C. (2012). Understanding the theory of change in international development: $A$ review of existing knowledge. Retrieved September 10, 2020, from https://www.gov.uk/research-for-development-outputs/understanding-theory-ofchange-.

SurveyMonkey. (2020). Steps to make sure your sample accurately estimates your population. Retrieved September 6, 2020, from surveymonkey.com.

Tamer, S. C., Pervez, N. G., \& Ayse, A. (2013). Doing business in emerging markets. (2nd ed.). London: SAGE.

The Economic Times. (2018). Ease of doing biz ranking: Gujarat to seek clarification from DIPP. p. 1. Retrieved June 7, 2020, from https://economictimes.indiatimes.com/news/economy/policy.

Tseng, Y., Yue, W., \& Taylor, M. (2005). The role of transportation in logistics chain. . Proceedings of the Eastern Asia Society for Transportation Studies, 5, 1657-1672. Retrieved from https://www.semanticscholar.org/paper/THE-ROLE-OFTRANSPORTATION-IN-LOGISTICS-CHAIN-.

USAID, U. S. (2020). Nigeria power Africa factsheet. Retrieved September 14, 2020, from www. usaid.gov.

Valters, C. (2014). Theories of change in international development: Communication, learning, or accountability? . Retrieved Setember 10, 2020, from https://www.researchgate.net/publication/291833177.

Vogel, I. (2014). Review of the use of theory of change' in international development. Retrieved from https://www.oxfamblogs.org/fp2p/wp-content/uploads/DFIDToC-.

Vogiatzoglou, K. (2016). Ease of doing business and FDI inflows in ASEAN. Journal of Southeast Asian Economies, 33(3), 343-363.

Weiss, C. H. (1995). Nothing as Practical as Good Theory: Exploring Theory-Based Evaluation for Comprehensive Community Initiatives for Children and Families. In J. Connell, A. Kubisch, L. Schorr, \& C. Weiss (Eds.), New Approaches to Evaluating Community Initiatives' ed.). Aspen Institute,. Washington, DC:, United State of America.

World Bank. (2020a). Doing business 2020 comparing business regulations in 190 economies. doi:10.1596/978-1-4648-1440-2. 
Jurnal Economia, Volume 17, Number 1, April 2021

World Bank. (2020b). GDP per capita (current US\$) - Nigeria. Retrieved May 16, 2020, from https://data.worldbank.org/indicator/NY.GDP.PCAP.CD?locations=NG.

World Bank. (2020c). Doing business measuring business regulations. World Bank. Retrieved June 20, 2020, from https://www.doingbusiness.org/en/methodology.

Yusuf, M. (2020). LCCI comments on second quarter GDP report. Retrieved September 14, 2020, from https://www.lagoschamber.com/lcci-comments-on-second-quartergdp-report/. 
Dear Respondent,

\section{QUESTIONNAIRE}

\section{FEBRUARY 2020}

I am conducting a research study which requires that I obtain your opinion on the ease of doing business in Nigeria. I am grateful for your assistance in completing this questionnaire, which is designed to gather research information only for academic purposes. I believe that this research will be of great value to me and the people of Nigeria. Your candid answers will be highly appreciated. Absolute confidentiality is guaranteed. Thank you for your cooperation.

Yours sincerely,

Signed under researcher's name

\section{SECTION A}

\section{RESPONDENTS ORGANISATION'S INFORMATION}

Please read the questions below; tick $(\sqrt{ })$ and fill as appropriate

1. Age of Organisation

2. Organisation's operational experience in Nigeria (a) 1-5 Years $\square$ (b) 6-10Years $\square$ (c) above 10 Years

3. Line of Business (a) Education (b) Agro-allied (c) General merchandise (d) Health (e) Hospitality (f) Entertainment (g) House hold (h)

Fashion (i) others

4. Business Headquarters Location: (a) Ikeja/ Mainland axis $\square$ (b) Badagry axis $\square$ (c) Ikorodu axis $\square$ (d)Lagos Island axis $\square$ (e) Epe axis $\square$

5. Number of branches/Offices in each Location:

\begin{tabular}{|l|l|l|l|l|l|}
\hline S/N & Location & \multicolumn{2}{l|}{ Number of branches } & \multicolumn{2}{l|}{} \\
\cline { 5 - 6 } & & $1-5$ & $6-10$ & $10-15$ & Above 15 \\
\hline A & Ikeja/ Mainland axis & & & & \\
\hline B & Badagry axis & & & & \\
\hline C & Ikorodu axis & & & & \\
\hline D & Lagos Island axis & & & & \\
\hline E & Epe axis & & & & \\
\hline
\end{tabular}

\section{SECTION B}

Instruction: Kindly allocate scores to the statements below by ticking $(\sqrt{ })$ the appropriate answer either by percentage score or number of days' score as indicated in each question

Guide to Percentage Score: (a) below 40\% = $1 \square$ (b) $40-50 \%=2 \square$ (c) $51-60 \%=3$ (d) $61-70 \%=4$ (e) $70-80 \%=5$ (f) Above $80 \%=6$

\begin{tabular}{|l|l|l|l|l|l|l|}
\hline & EASE OF DOING BUSINESS CRITERIA & \multicolumn{3}{l|}{ SCORES } & \multicolumn{2}{l|}{} \\
\hline & YEAR & 2015 & 2016 & 2017 & 2018 & 2019 \\
\hline 6. & Ease of government procurement process (No of Days) & & & & & \\
\hline 7. & Traffic and Transportation management (\%) & & & & & \\
\hline 8. & Availability of raw materials/ Goods (\%) & & & & & \\
\hline 9. & Power supply (\%) & & & & & \\
\hline 10. & Quality of Workforce available for hire (\%) & & & & & \\
\hline 11. & Government policy continuity (\%) & & & & & \\
\hline 12. & Security infrastructure (\% score) & & & & & \\
\hline 13. & Return on investment \% & & & & & \\
\hline
\end{tabular}

